\title{
UPAYA MENINGKATKAN KETERAMPILAN MEMBACA PERMULAAN BAHASA INDONESIA DENGAN MENGGUNAKAN MEDIA BIG BOOK PADA PESERTA DIDIK KELAS I SDN 24 TEMMALEBBA KOTA PALOPO
}

\author{
Misrawati \\ Program Studi Pendidikan Guru Madrasah Ibtidaiyah \\ Institut Agama Islam Negeri Palopo \\ Jl. Agatis Balandai Kota Palopo Propinsi Sulawesi Selatan \\ E-mail: misrawati121995@gmail.com
}

\begin{abstract}
This research aims to determine the improvement of beginning skill through big book media on the students of class I SDN 24 Temmalebba Palopo city. This research uses the qualitative and quantitative approach with Classroom Action Research (PTK) which is designed through two cycles. Research subjects, students of SDN 24 Temmalebba class I which amounted to 28 students. Data collection techniques used, namely observation, documentation, and tests. The research data obtained were analyzed by using descriptive statistic formula (percentage) to express descriptively the research result. Furthermore, to discuss and explain the results of research that is quantitative descriptive then used the technique of data reduction analysis, data presentation, and drawing a conclusion. The research results found that in precycle stage, with the average value of reading skill beginning is 51,5 with mastery learning classical $25 \%$. After implementing the learning by applying the big book media, in the first cycle, the average score of reading skill is 66.71 students with $57.14 \%$ classical learning completeness. Furthermore, in cycle II with the average score of simple writing skill is 75.21 with $89.28 \%$ classical learning completeness. Thus, the initial reading skill in class I SDN 24 Temmalebba Palopo City by applying the big book media conducted from the first cycle to the 2 show significant results. Therefore, the big book media needs to be referenced by the teacher in the activity.
\end{abstract}

Keywords: Beginning Reading Skills, Big Book Media, Indonesian Language

\begin{abstract}
Abstrak
Penelitian ini bertujuan untuk mengetahui peningkatan keterampilan permulaan melalui media big book pada siswa kelas I SDN 24 Temmalebba Kota palopo. Penelitian ini menggunakan pendekatan kualitatif dan kuantitatif dengan jenis Penelitian Tindakan Kelas (PTK) yang didesain melalui dua siklus. Subjek penelitian, siswa-siswi SDN 24 Temmalebba kelas I yang berjumlah 28 siswa. Teknik pengumpulan data yang digunakan, yaitu observasi, dokumentasi,dan tes. Data penelitian yang diperoleh dinalisis dengan menggunakan rumus statistik deskriptif(persentasi) untuk mengungkapkan secara deskriptif hasil penelitian. Selanjutnya, untuk membahas dan menjelaskan hasil penelitian yang bersifat kuantitatif deskriptif maka digunakan teknik analisis reduksi data, penyajian data, dan penarikan kesimpulan.Hasil penelitian ditemukan bahwa pada tahap prasiklus, dengan nilai rata-rata keterampilan membaca permulaan adalah 51,5 dengan ketuntasan belajar klasikal 25\%. Setelah dilaksanakan pembelajaran dengan menerapkan Media big book, pada siklus I maka nilai rata-rata keterampilan membaca permulaan siswa adalah 66,71 dengan ketuntasan belajar klasikal 57,14\%. Selanjutnya, pada siklus II dengan nilai rata-rata keterampilan menulis karangan sederhana adalah 75,21 dengan ketuntasan belajar klasikal 89,28\%.Dengan demikian, keterampilan membaca permulaan di kelas I SDN 24 Temmalebba Kota Palopo
\end{abstract}




\section{4 | Misrawati}

dengan menerapakan media big book yang dilakukan mulai dari siklus pertama sampai ke-2 menunjukkan hasil yang signifikan. Oleh karena itu, media big book perlu dijadikan referensi oleh guru dalam kegiatan.

Kata Kunci: Bahasa Indonesia, Keterampilan Membaca Permulaan, Media Big Book

\section{PENDAHULUAN}

Bahasa resmi Republik Indonesia yaitu bahasa Indonesia itu sendiri yang merupakan alat komunikasi digunakan oleh bangsa Indonesia sebagai alat berkomunikasi. Pembelajaran bahasa Indonesia merupakan salah satu pelajaran yang wajib ada disetiap sekolah yang ada diIndonesia. Pada pembelajaran bahasa Indonesia memiliki empat keterampilan yang harus dikuasai siswa, yaitu keterampila 1) mendengar atau menyimak (listening skills), 2) berbicara (speaking skill), membaca (reading skill) dan menulis(writing skill).yangmemiliki manfaat masing-masing. Nida dan Tarigan (1981:1). "Bahasa merupakan produk budaya yang berharga dari generasi ke genarasi berikutnya. Bahasa adalah hasil budaya yang hidup dan berkembang yang haris dipelajari, seoranga anak manusia yang tidak pernah diajar berbicara, maka tidak akan pernah memiliki kemampuan berbicara". Zulela (2013:3). Sedangkan bahasa menurut woster's Thirt New International Dictionari of the English Languare dalam buku Sukirman Nurdjan dan Edhy Rustan "Bahasa adalah alat yang sistematis untuk menyampaikan gagasan atau perasaan dengan memakai tanda-tanda, bunyibunyi, gesture, atau tanda-tanda yang disepakati, yang mengandung makna yang dapat dipahami" (Sukirman \& Rustan, 2010). Bahasa digunakan sebagai media dalam berkomunikasi yakni membantu seseorang menyampaikan pesan dan mengekspresikan emosi dalam merespon lingkungan (Rustan \& Subhan, 2018).

Membaca permulaan merupakan tahap awal anak belajar membaca dengan fokus ada pengenalan simbol- simbol huruf dan aspek- aspek yang mendukung pada kegiatan membaca selanjutnya. Setiap orang akan belajar membaca terlebih dahulu memasuki tahap membaca permulaan. Tahap ini merupakan tahapan awal dalam belajar membaca. Dalam hal ini, membaca permulaan bersifat mekanis yang dapat dianggap berada pada urutan yang 
lebih rendah. Membaca Permulaan merupakan suatu keterampilan awal yang harus dipelajari atau dikuasai oleh pembaca. Membaca permulaan adalah tingkat awal agar orang bisa membaca". Dalman ( 2008:85). Tujuan utama pengajaran membaca dan menulis permulaan adalah mendidik anak- anak dalam waktu singkat dan cara yang mudah agar ia mampu membaca dan menulis. Kepandaian membaca dan menulis permulaan merupakan dasar bagi anak untuk memperluas ilmu pengetahuan dan mengembangkan pribadinya pada masa selanjutnya". M.Subana dan Sunarti (1965:236). Membaca adalah aktivitas yang komplek yang melibatkan berbagai faktor datangnya dari dalam diri pembaca maupun dari luar pembaca. (Meliyawati 2016:3). Menurut Soedarso (2006:4) membaca adalah aktivitas yang kompleks dengan menerapkan dan mengarahkan sejumlah besar tindakan yang terpisah- pisah, orang hrus menggunakan pengertian dan khayalan, mengamati dan mengingat- ingat. Untuk dapat memahami suatu isi bacaan dengan baik diperlukan adanya kemampuan membaca pemahaman yang baik pula. Pemahaman merupakan salah satu aspek yang sangat penting dalam kegiatan membaca, sebab pada hakikatnya pemahaman suatu bahan bacaan dapat meningkatkan keterampilan membaca itu sendiri maupun untuk tujuan tertentu yang hendak dicapai”. Firman (2015:9).

Secara harfiah kata media memiliki arti " perantara" atau " pengantar". Association for Education and Communication Technolohy ( AECT) mendefenisikan media yaitu segala bentuk yang dapat di amnipulasikan, dilihat, didengar, dibaca atau dibicarakan beserta instrumen yang dipergunakan denagn baik dalam kegiatan belajar mengajar, dapat mempengaruhi efektifitas program instruktional.Dari defenisi tersebut dapat ditarik kesimpulan bahwa pengertian media merupakan sesuatu yang bersifat menyalurkan pesan dan dapat merangsang pikiran, perasaan, dan kemauan audien ( siswa) sehingga dapat mendorong terjadinya proses belajar pada dirinya. Penggunaan media secara kreatif akan memungkinkan audien ( siswa) untuk belajar lebih baik dan dapat meningkatkan performan mereka sesuai dengan tujuan yang ingin dicapai" (Asnawir dan Basyiruddin : 2002). 


\section{$176 \mid$ Misrawati}

Bila media adalah sumber belajar, maka secara luas media dapat diartikan dengan manusia, benda ataupun peristiwa yang memungkinkan anak didik memperoleh pengetahuan dan keterampilan". Syaiful Bahri Djamarah, dan Aswan Zain ( 2010:120). Media berfungsi untuk tujuan intruksi dimana informasi yang terdapat dalam media itu harus melibatkan siswa baik dalam benak atau mental maupun dalam bentuk aktivitas yang nyata sehingga pembelajaran dapat terjadi. Materi harus dirancang secara lebih sistematis dan psikologis dilihat dari segi prinsip- prinsip belajar agar dapat menyiapkan intruksi yang efektif. Di samping menyenangkan, media pengajaran harus dapat memberikan pengalaman yang menyenangkan dan memenuhi kebutuhan perorangan siswa."Azhar Arsyad (2007:26).

Big book merupakan buku bacaan yang memiliki ukuran, tulisan, dan gambar yang besar. Ukuran big book bisa beragam, misalnya ukuran A3, A4, A5 atau seukuran koran. Ukuran big book harus mempertimbangkan segi keterbacaan seluruh siswa dikelas. Big book dapat digunakan dikelas awal karena memilki karakteristik yang sesuai dengan kebutuhan siswa. Big book sangat baik dipergunakan dikelas awal karena dapat membantu meningkatkan minat siswa dalam membaca". Tri Nur Mufida (2017:33). ). Media ini sangant baik digunakan dalam melatih keterampilan membaca permulaan siswa agar siswa teransang untuk menanggapi pendapat kelompok lain dengan menggunakan idea atau pikirannya.

Berdasarkan pra tindakan yang dilakukan oleh penulis pada SDN 24 Temmalebba Kota Palopo yaitu Permasalahan pada observasi awal yang peneliti temukan diantaranya rendahnya keterampilan membaca permulaan siswa dan siswa merasa malu dalam menyampaikan ide atau pendapatnya. Sehingga peneliti memilih media big book yang dapat melatih keterampilan membaca siswa serta memberikan motivasi sehingga siswa tertarik untuk mengemukakan ide atau pikirannya sendiri. Untuk mengetahui sejau mana pemahaman siswa terhadap materi yang diberikan yaitu dengan melakukan observasi dan memberikan tes awal. Dari 28 siswa yang menjadi sampel sekaligus ikut dalam melakukan tes awal ternyata 1 sangat baik, 6 siswa yang mendapat nilai termasuk kategori baik, 7 siswa termasuk kategori cukup, dan 14 siswa termasuk kategori kurang dan mendapatkan nilai rata-rata 51,5 .

Alasan tersebut mendorong peneliti untuk melaksanakan penelitian dengan menggunakan media big book untuk meningkatkan keterampilan membaca siswa. Dalam menerapkan media big book, ada bebrapa langakahlangkah diperhatikan antara lain:"1) Guru membaca buku dengan menggunakan media big book, 2) Siswa menyimak bacaan guru, 3) Guru dan siswa membaca big book secara bersama- sama, 4) Guru menunjuk salah satu siswa secara bergantian untuk membaca big book". Tri Nur Mufida 
(2017:33). Dengan adanya langkah-langkah ini memudahkan seorang guru dalam melaksanakan media ini. Jika seseorang terampil dalam berbicara dia tidak akan merasa kesulitan dalam berkomunikasi dengan orang lain baik secara langsung (tatap muka) atau pun dengan jarak jauh. Hal ini sejalan dengan pendapat Anwar Arifin (2008:30) Pendidikan dapat disalurkan dengan berbagai cara yang salah satunya adalah dengan berbicara. Di dalam ilmu komunikasi, berbicara termasuk dalam komunikasi langsung (tatap muka), dipelajari dibawa namakomunikasi bicara (speech communication).

Faktor-faktor yang menyebabkan rendahnya kemampuan membaca siswa dapat disebabkan oleh beberapa faktor, yaitu faktor yang berasal dari diri siswa maupun dari luar diri siswa. Sebaiknya jangan memicu perasaan negatif terhadap membaca untuk meningkatkan keterampilan membaca siswa. Juga, jangan memusatkan perhatian pada kesalahan-kesalahan atau masalah-masalah yang ditimbulkan oleh siswa". Ferni Olivia ( 2008:18). Hal ini disebabkan faktor fisiologis, psikis, motivasi dan pengalaman-pengalaman sebelumnya akan menjadi stimulus pembangkit inspirasi positif dalam menyelesaikan tugas atau persoalan yang dihadapi (Thaha \& Rustan, 2017). Membaca menjadi salah satu kompetensi yang sangat ditekankan. Kompetensi siswa SD, dapat dibagi menjadi dua tahapan (a) membaca permulaan dan (b) membaca tahap lanjut," R. Masri Sareb Putra ( 2008:4-5). Karakteristik siswa yang kompleks tersebut menjadikan pijakan dasar untuk menentukan strategi pembelajaran yang akan digunakan. Demikian pula, siswa yang memiliki gaya belajar visual, tentu berbeda penerapan strategi pembelajaran terhadap siswa yang memiliki gaya belajar kinestik. Oleh sebab itu, berperan menjadi guru hendaknya dapat memahami karakteristik siswa yang mengikuti proses pembelajaran.

\section{METODE}

Jenis penelitian yang digunakan adalah penelitian tindakan kelas (PTK) yang menggunakan pendekatan kualitatif dan kuantitatif. Penelitian ini dilaksanakan di SDN 24 Temmalebba Kota Palopo. 1) Sumber Data, pada penelitian ini peneliti menggunakan dua jenis data untuk mendukung penelitiannya adalah: a) Data primer adalah Observasi dengan pihak sekolah terkhususnya kepala Sekolah dan guru kelas 1 SDN 24 Temmalebba. b) Data sekunder iayalah data yang didapatkan dari data tertulis berupa profil sekolah, data guru, data siswa, serta sarana dan prasarana yang ada di sekolah tersebut yang dibutuhkan untuk kelengkapan dalam penelitian. 2) Subjek Penelitian, Subjek penelitian adalah siswa-siswi kelas 1 SDN 24 Temmalebba Kota Palopo, berjumlah 28 siswa yang terdiri dari 13 laki-laki dan 15 perempuan pada semester ganjil tahun pelajaran 2017/2018. 
Pengelolaan data dilakukan setelah terkumpulnya data pada penelitian. Selanjutnya dianalisis secara kuantitatif dan kualitatif. Untuk analisis secara kualitatif dan kuantitatif. Untuk analisis secara kuantutatif digunakan analisis secara statistik deskriptif yaitu skor rata-rata dan persentase.Sedangkan analisis kualitatif dilakukan terhadap data yang diperoleh melalui observasi aktivitas belajar siswa dan guru dalam penerapan Media big book untuk meningkatkan keterampilan membaca siswa. Analisis ini dihitung dengan menggunakan rumus statistik sederhana.

\section{TINJAUAN PENERAPAN MEDIA BIG BOOK}

Penerapan media big book dalam meningkatkan keterampilan membaca pada siswa yakni dengan menyediakan media big book yang dimana gambar tersebut berisikan cerita dan langsung diambil berdasarkan kegiatan yang selalu dialami oleh siswa sehingga siswa tidak akan ragu untuk membaca karena gambar berada dekat dan menjadi aktifitas yang biasanya dikerjakan dan ada pada lingkungan keseharian mereka seperti gotong royong, pasar dan lingkungan alam sehingga dengan gambar tersebut siswa akan menceritakan langsung kegiatan gambar tersebut dengan menyimak dan membaca cerita secara langsung di depan kelas, dengan cara ini siswa akan diharuskan untuk membaca karena gambar yang telah disediakan tersebut akan memaksakan siswa untuk membaca dengan menggunakan bahasa mereka sendiri dengan bantuan bimbingan guru sehingga dengan diterapkannya media big book dapat meningkatkan keterampilan membaca pada siswa kelas 1 di SDN 24 Temmalebba kota palopo.

Setelah peneliti menerapkan media big book pada siswa kelas 1 SDN 24 Temmalebba Kota Palopo, dapat diketahui pada keterampilan membaca siswa selalu meningkat. Hal tersebut dapat diketahui berdasarkan hasil tes keterampilan membaca yang dilakukan pada setiap akhir pertemuan dari prasiklus, siklus I sampai dengan siklus II. Peningkatan digambarkan dalam bentuk diagram sebagai berikut:

\section{Hasil Tes Keterampilan Membaca}

$$
\square=51,5 \square 66,71 \quad \square 75,21
$$

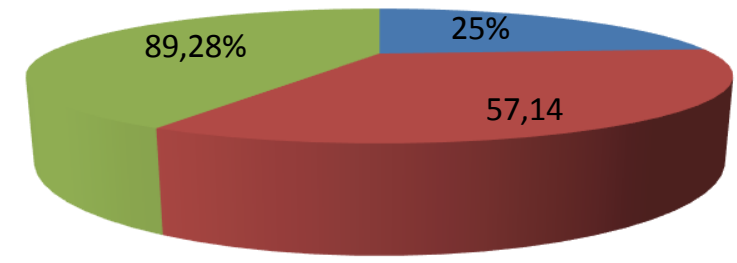


Diagram tersebut menunjukkan bahwa peningkatan keterampilan membaca pada siswa mengalami peningkatan dalam setiap siklusnya sehingga mencapai nilai KKM. Proses latihan membaca terlebih dahulu akan menimbulkan kepercayaan diri untuk berani membaca dengan selalu melakukan latihan di kelas ataupun di rumah untuk membaca sehingga mereka tidak akan malu-malu ataupun takut karena dengan penguatan yang diberikan oleh guru dan siswa lainnya.

\section{MENERAPKAN MEDIA BIG BOOK}

Hasil penelitian terdiri dari aktivitas siswa dan guru dalam pembelajaran keterampilan membaca dengan menerapkan media big book pada siswa kelas 1 SDN 24 Temmalebba Kota Palopo. Pelaksanaan pembelajaran terdiri dari 4 langkah pembelajaran yaitu: 1) Tahap menyampaikan tujuan pembelajaran, 2) Tahap menjelaskan prosedur penggunaan media big book, 3) Tahap melaksanakan pembelajaran keterampilan membaca, dan 4) Tahap mempertahankan argument atau ide. Keempat langkah tersebut dirangkum menjadi tiga kegiatan yaitu: 1) Kegiatan awal, 2) Kegiatan inti, dan 3) Kegiatan akhir. Berdasarkan hasil observasi yaitu kemampuan dalam melaksanakan pembelajaran menggunakan media big book, bersama rekan sejawat dilakukan refleksi bahwa terdapat beberapa indikator yang harus diperbaiki terutama pada indikator membuat hipotesis, melakukan kegiatan verifikasi, melakukan aplikasi konsep, dan pemanfaatan waktu. Keempat indikator ini menjadikan catatan tersendiri yaitu dalam membuat hipotesis dibuat dalam bentuk sederhana sesuai dengan metode yang akan dilakukan. Verifikasi dilakukan harus sesuai dengan alat dan bahan serta berdasarkan hipotesis yang telah disusun. Aplikasi konsep yang harus dilakukan harus sesuai dengan materi pembelajaran, alat dan bahan hipotesis yang disusun. Terpenting adalah pembatasan waktu, dalam pembatasan waktu yang harus ditentukan, yaitu lamanya waktu dan dikarenakan dalam pembelajaran tidak dilakukan pembatasan waktu akibatnya ketika jam berakhir pembelajaran masih berlangsung. Hasil refleksi terhadap belajar siswa berdasarkan siklus I bahwa hasil pembelajaran perlu ditingkatkan dikarenakan perolehan nilai siswa yaitu nilai rata -rata masih rendah. Masukan dalam diskusi antara guru dan rekan sejawat bahwa dalam pembelajaran pada kegiatan elaborasi dapat diinformasikan tentang materi pembelajaran. Berdasarkan hasil refleksi maka disimpulkan perlu tindakan lebih lanjut atau siklus II dengan melakukan penggantian submateri.

Berdasarkan pembelajaran tindakan siklusII peneliti sudah mampu melaksanakan pembelajaran secara optimal, dimana keempat tahapan 
pembelajaran dengan menggunakan metode debat sudah mampu diaplikasikan dengan baik, sehingga berdampak pada peningkatan pemahaman siswa dalam memahami materi, dimana pada tindakan siklus II ini pemahaman siswa dalam memahami materi sudah sesuai dengan yang diharapkan. Hal ini terlihat dari hasil tes evalusi siklus I dengan nilai ratarata 66,71 dan kriteria ketuntasan belajarnya mencapai 57,14\%, mengalami peningkatan pada siklus II yakni nilai rata-rata75,21 dengan kriteria ketuntasan belajarnya mencapai 89,28\%.

Tujuan pembelajaran yang telah ditetapkan telah tercapai dengan baik, siswa juga sudah mampu mengungkapkan argumen atau idenya masingmasing untuk mempertahankan pendapatnya. Pemahaman siswa mengenai materi yang diajarkan telah meningkat. Peningkatan juga terjadi karena adanya motivasi yang guru berikan kepada siswa, siswa merasa terangsang serta terdorong untuk melakukan kegiatan yang berhubungan dengan pembelajaran yang sedang berlangsung sehingga nilai rata-rata yang siswa dapatkan meningkata atau mengalami perubahan. Hal ini sejalan dengan pendapat David McClelland et al, yang dikutip oleh Hamzah B Uno (2015:9). yaitu "motif merupakan implikasi dari hasil pertimbangan yang telah dipelajari (redintegration) dengan ditandai suatu perubahan pada situasi afektif. Sumber utama munculnya motif adalah dari rangsangan (stimulasi) perubahan situasi sekarang dengan situasi yang diharapkan , sehingga tanda perubahan tersebut tampak pada adanya perbedaan afektif saat munculnya motif dan saat usaha pencapaian diharapkan, sehingga tanda perubahan tersebut tampak pada adanya perbedaan".

Selain pemberian motivasi guru juga memberika hadiah pada siswa yang mendapat nilai tertinggi pada akhir pembelajaran untuk membangkitkan semnagat belajar siswa. Seperti pendapat Mamiq Gaza (2012:88) teknik memberikan reward atau bonus belajar menyenagkan bagi siswa yang berhasil menunjukkan prilaku posif-positif tertentu. Pendapat lain yang sama yaitu B.F Skinner (Sudarwan Danim Khair, 2014:107) siswa akan mengulangi prilaku yag diinginkan jika prilaku yang positif. Penguatan positif atau "imbalan" dapat mencakup penguatan verbal seperti "bagus", "bagus sekali", "sukses selalu", "pertahankan prestasimu", dan sebagainya. Pendekatan yang digunakan dalam pendekatan ini ialah sebuah pendekatan yang menerapkan proses interaksi antara siswa satu dan siswa lainnya sehingga akan berpengaruh pada interaksi dalam sosial masyarakat tersebut. Proses pembelajaran yakni belajar dan interaksi mengajar hendaknya lebih mengembangkan keterampilan dan kesanggupan siswa mengadakan hubungan erat dengan orang lain/siswa yang ada pada lingkngan mereka, menunjukkan sikap dan perilaku demokratis, serta menumbuhkan keaktifan kegiatan dalam belajar pada siswa (Nana Sudjana, 2011: 155). Hal ini 
menunjukkan bahwa, penerapan media big book adalah salah satu media yang cocok diterapkan dalam meningkatkan keterampilan membaca siswa terhadap mata pelajaran bahasa Indonesia. Hal ini terlihat dari perubahan atau peningkatan nilai rata-rata yang di capai oleh siswa yaitu dari prasiklus 51,5 dengan ketuntasan 25\%, siklus I 66,71 dengan ketuntasan 57,14\%, dan siklus II 75,21 denga ketuntasan 89,28\%.

\section{PENUTUP}

Hasil analisis data penelitian, serta rumusan masalah maka dapat disimpulan bahwa:1)Setelah diadakan penelitian dengan penerapan media big book pada siswa kelas 1 SDN 24 Temmalebba Kota Palopo lebih mudah untuk meningkatkan pembelajaran khususnya dalam keterampilan membaca Bahasa Indonesia. 2) Dengan menggunakan media big book dalam proses pembelajaran yang dilakukan secara bertahap yaitu dua siklus mengalami suatu peningkatan yang cukup signifikan dimana keterampilan membaca siswa pada siklus I yang masih berkategori 'Cukup' dengan ratarata 66,71 dengan ketuntasan belajar 57,14\% meningkat pada siklus II dengan kategori 'Baik' dengan rata-rata 75,21 dan ketuntasan belajar 89,28\%. Dengan demikian penerapan pembelajaran media big book untuk peningkatan keterampilan membaca siswa kelas 1 SDN 24 Temmalebba Kota Palopo.

\section{DAFTAR PUSTAKA}

Arifin Anwar. 2008, Ilmu Komunikasi: Sebuah Pengantar Ringkas, Cet. I: Jakarta; PT Raja Grafindo Persada.

Arsyad, Azhar Arsyad. 2007. Media Pembelajaran, Jakarta: PT Rajagrafindo Persada, 2007), h. 26

Aswan Zain dan Syaiful Bahri Djamarah. 2010. Strategi Belajar Mengajar. Jakarta: Rineka Cipta.

Dalman.2014. Keterampilan Membaca. Ed. I, Cet, 2. Jakarta: PT Raja Grafindo Persada.

Denim, Sudarwan. 2011. Pengantar Pendidikan. Cet. II. Bandung: Alfabeta.

Ferni Olivia. 2008. Tools For Study Skills Teknik Membaca Efektif. Jakarta: PT Elex Media Komputindo.

Firman. 2015. Terampil Menulis Karya Tulis Ilmiah. Makassar: Aksara Timur.

Gaza Mamiq. 2012. Bijak Memghukum Siswa, Cet. I, Jokjakarta: Ar-ruzz Media.

M.Basyiruddin Usman dan H. Asnawir. 2002. Media Pembelajaran. Jakarta: Ciputat.

Meliyawati. 2016. Pemahaman Dasar Membaca. Yogyakarta: Deepublish. 
Muhadi. 2011. Penelitian Tindakan Kelas. Yogyakarta. Shira Media.

Nurdjan, S., \& Rustan, E. (2010). Kunci Sukses Berbahasa Indonesia. Palopo: Lembaga Penerbitan STAIN (LPS) STAIN Palopo.

Rustan, E., \& Subhan. (2018). Komunikasi Verbal Anak Pesisir Usia 7-8 Tahun Pada Transakasi Penjualan Produk Kebudayaan Dengan Turis mancanegara. Jurnal Pendidikan Usia Dini, 12(1), 12-28. https://doi.org/10.21009/JPUD.121 02

R. Masri Sareb Putra. 2008. Menumbuhkan Minat Baca Sejak Dini. Jakarta: PT Macana Jaya Cemerlang.

Soedarso. 2006. Speed Reading Sistem Membaca Cepat dan Efektif. Jakarta : PT Gramedia Pustaka Utama.

Sudjana Nana, 2011. Dasar-dasar Proses Belajar Mengajar. Cet XII: Bandung: Sinar Baru Algensido.

Sunarti dan M. Subana. 1965. Strategi Belajar Mengajar. Bandung: Pustaka Setia.

Syamsu S. 2015, Strategi Pembelajaran Meningkatkan Kompetensi Guru. Cet I: Makassar: Aksara Timur.

Thaha, H., \& Rustan, E. (2017). Orientasi Religiusitas dan Efikasi Diri dalam Hubungannya dengan Kebermaknaan Pendidikan Agama Islam pada Mahasiswa IAIN Palopo. Studi Agama Dan Masyarakat, 13(2), 163179.

Tri Nur Mufidah. 2017. Peningkatan Kemampuan Membaca Pemahaman Melalui Media Big Book pada Siswa Kelas III SD Negeri I Bero Klaten.

Uno, B, Hamsa. 2015. Teori Motivasi \& Pengukurannya Analisis Di Bidang Pendidikan, Cet. XII; Jakarta, PT Bumi Aksara.

Zulela. 2013. pembelajaran Bahasa Indonesia, Apresiasi Sastra di Sekolah Dasar, Cet,II: Bandung; PT Remaja Rosdakarya. 